\title{
Optimization of Culture Conditions for Protease Production using Three Strains of Bacillus
}

\author{
Cyr Jonas Morabandza ${ }^{1,4}$, Valentin Dibangou ${ }^{1,2}$, Faly Armel Soloka Mabika ${ }^{1,2 *}$ (D), \\ Elgie Viennechie Gatse ${ }^{1,2}$, Tarcisse Baloki Ngoulou ${ }^{1,2}$, Ngo-Itsouhou ${ }^{1,2}$ and \\ Etienne Nguimbi ${ }^{1,2,3}$
}

\begin{abstract}
${ }^{1}$ Laboratoire de Biologie Cellulaire et Moleculaire, Faculte des Sciences et Techniques, Universite Marien Ngouabi, Brazzaville, Republique du Congo.

${ }^{2}$ Unite de Microbiologie Moleculaire et Bioinformatique, Faculte des Sciences et Techniques, Universite Marien Ngouabi, Brazzaville, Republique du Congo.

${ }^{3}$ Institut de Recherche en Sciences Exactes et Naturelles (IRSEN), Avenue de l'auberge Gascogne Cite Scientifique (Ex. OROSTOM) Brazzaville, Republique du Congo.

${ }^{4}$ Ecole Normale Superieure, Universite Marien Ngouabi, Brazzaville, Republique du Congo.
\end{abstract}

\begin{abstract}
The aim of this work was to determine the effect of a few external factors on bacterial growth and the production of enzymes with a proteolytic effect in three strains of Bacillus: CMS5 (Bacillus subtilis), CMS4 (Bacillus sp.) and SPo5 14' (Bacillus velenzensis) isolated from squashes packed in traditionally prepared cassava leaves, but also to determine the best source of carbon and nitrogen. All three strains have the ability to actively degrade milk casein. The strains were grown in Luria Bertani medium and the suspension from the cell culture was used to measure optical density and demonstrate enzyme activity on a petri dish containing skim milk. Several parameters were verified including the influence of temperature, $\mathrm{pH}$, and carbon and nitrogen source on growth and enzyme production. Growth was possible from 25 to $60^{\circ} \mathrm{C}$ with an optimal temperature of $30^{\circ} \mathrm{C}$ after 24 hours. Enzyme production was observed from 25 to $55^{\circ} \mathrm{C}$ with an optimum at $37^{\circ} \mathrm{C}$. For $\mathrm{pH}$, growth and enzyme production was possible from pH 5.7 and 9 with an optimum of 7 in all three strains. Among the sources of carbons used, galactose is the best source for growth after $24 \mathrm{~h}$ in all three strains, and starch for production. Among nitrogen sources, Bacto-peptone is best for growth as well as production.
\end{abstract}

Keywords: Optimization, production, protease, strain, Bacillus

*Correspondence: armelmabika@gmail.com

(Received: November 22, 2020; accepted: March 03, 2021)

Citation: Morabandza CJ, Dibangou V, Mabika FAS, et al. Optimization of Culture Conditions for Protease Production using Three Strains of Bacillus. J Pure Appl Microbiol. 2021;15(2):621-629. doi: 10.22207/JPAM.15.2.05

(C) The Author(s) 2021. Open Access. This article is distributed under the terms of the Creative Commons Attribution 4.0 International License which permits unrestricted use, sharing, distribution, and reproduction in any medium, provided you give appropriate credit to the original author(s) and the source, provide a link to the Creative Commons license, and indicate if changes were made. 


\section{INTRODUCTION}

Microorganisms, through their activities, are today used in the different branches of industry, namely: the chemical, agro-food and pharmaceutical industries. Today microbes are used in different industries like chemical, food and pharmaceutical ${ }^{1,2}$. They are remarkable agents of degradation. Indeed, in their natural environment, they participate in the biodegradation of even the most complex organic matter (cellulose, lignin, chitin and pectin) thanks to the production of various extracellular enzymes ${ }^{3}$. Among the microorganisms, bacteria are one of the groups known, together with fungi, for the production of substances of biotechnological interest, including hydrolytic enzymes.

Current biotechnological advances have made it possible to set up processes exploiting microbe al properties in the various fields of life, which have a wide range of applications ${ }^{4}$. Proteases, amylases, cellulases and other hydrlolytic enzymes, developed by bacteria particularly the genera Pseudomonas, Bacillus and Alteromonas Penicillium Enterobacter, are widely used. Lipases produced by Serratia, Pseudomonas, Fusarium and Alternaria are also used in the dairy, detergent and even biodiesel industries. ${ }^{5}$

The genus Bacillus, with its rapid growth and highly developed enzymatic production due to its genetic heritage, is used in a wide range of biotechnological fields ${ }^{6}$. Under particular conditions (density of the inoculum, presence of metal ions, metabolisable substrate, temperature, $\mathrm{pH}$ and oxygen requirement) the Bacillus genus produces extracellular enzymes. Several previous studies on the enzymatic production from microorganisms have optimised the growth and production of proteolytic enzymes, thus providing information on the close link between microbial growth and enzymatic production ${ }^{7}$. In Congo Brazzaville, it has been shown that many traditional fermented and unfermented foods contain bacteria of the genus Bacillus capable of producing hydrolytic enzymes.

In this work, three strains of bacteria of the genus Bacillus including Bacillus subtilis, Bacillus sp. and Bacillus velenzensis identified by their $16 \mathrm{~S} \mathrm{rDNA}^{8}$ isolated from cooked squashes sold in Brazzaville markets in the Republic of Congo were used for the study.

\section{MATERIAL AND METHODS}

Bacterial strains, culture conditions and bacterial growth

The three strains of Bacillus: Bacillus subtilis; Bacillus sp. and (Bacillus velenzensis); used in this work come from the collection of microorganisms isolated from crushed pumpkin seeds, packed cooked and sold in the markets of Brazzaville. These freeze-preserved strains of Bacillus were available at the Cellular and Molecular Biology Laboratory of the Faculty of Science and Technology of the Marien N'gouabi University. The cultures were carried out in Erlen Meyer containing $20 \mathrm{~mL}$ of fermentation medium (LB), cultured at $37^{\circ} \mathrm{C} .1 \mathrm{~mL}$ of the overnight culture was taken and transferred to an Erlen Meyer containing $100 \mathrm{~mL}$ of LB and incubated for 48 hours at $37^{\circ} \mathrm{C}$, then every 2 hours $3 \mathrm{~mL}$ was taken, of which $2 \mathrm{~mL}$ was used to measure the optical density. $1 \mathrm{ml}$ was centrifuged, the supernatant of which was used to detect and evaluate the enzymatic production ${ }^{7,9}$

\section{Protease production}

\section{Proteolytic enzyme assay and casein box}

To demonstrate the proteolytic activity of the strains, $1 \mathrm{~g}$ of agarose was dissolved in $100 \mathrm{ml}$ of PBS at 0.01 , then heated until the agarose was completely dissolved and allowed to cool. $10 \mathrm{ml}$ of skimmed milk was added. After homogenising, the medium was poured into the tins. $50 \mu \mathrm{l}$ of the bacterial supernatant from the centrifugation were placed in the tins and then placed in the oven. Incubation was carried out at $37^{\circ} \mathrm{C}$ for 12 hours.

The strains were qualified as having proteolytic potential after observation of the clear halos around the wells in which the supernatant had been deposited and the diameter of each of the translucent halos was measured ${ }^{10,11}$

Effect of temperature on the growth and production of proteolytic enzyme

The effects of temperature on growth and enzyme production were studied by varying the temperature. Thus we proceeded as follows, a fresh colony was inoculated in $20 \mathrm{ml}$ of the LB medium contained in erlenmeyer incubated overnight. On the following day, $1 \mathrm{ml}$ of the overnight culture was inoculated into the $100 \mathrm{ml}$ Erlenmeyer flask and incubated for 24 hours at temperatures between $25 ; 30 ; 37 ; 40 ; 45 ; 50 ; 55$; $60^{\circ} \mathrm{C}$. $3 \mathrm{ml}$ was taken, of which $2 \mathrm{ml}$ was used to 
measure the optical density and $1 \mathrm{ml}$ was kept for the detection of the enzyme activity ${ }^{10,11}$.

Effect of $\mathrm{pH}$ on the growth and production of the enzyme

The effect of $\mathrm{pH}$ on growth and protease production was evaluated. For this purpose, cultures were carried out on liquid LB media at different $\mathrm{pH}$ 's, 5, 7 and 9. A colony taken from the petri dish after transplantation was inoculated into the Erlenmeyer flask containing $20 \mathrm{ml}$ of LB medium, and then $1 \mathrm{ml}$ of the overnight culture inoculated into the Erlenmeyer flask containing $100 \mathrm{ml}$ was taken and incubated for 24 hours at $30^{\circ} \mathrm{C} .3 \mathrm{ml}$ are taken, of which $2 \mathrm{ml}$ is used to measure the optical density at $600 \mathrm{~nm}$ using a spectrophometer and the $\mathrm{pH}$ using $\mathrm{pH}$ paper and $1 \mathrm{ml}$ is stored for enzyme production $10,12,13$

Effect of various carbon and nitrogen sources on the growth and production of proteolytic enzymes

Carbon sources

The growth monitoring and extracellular enzyme production of three Bacillus strains were studied under the effect of different carbon sources containing different types of substrates: Galactose, Starch, Mannose. Sugars are used separately and a single source of nitrogen (yeast extract) is used in combination with mineral substances $\left(\mathrm{MgSO}_{4} .5 \mathrm{H}_{2} \mathrm{O} ; \mathrm{KH}_{2} \mathrm{PO}_{4} ; \mathrm{CaCl}_{2} .6 \mathrm{H}_{2} \mathrm{O} ; \mathrm{K}_{2} \mathrm{HPO}_{4}\right.$ ). In each medium $0.5 \%$ of the yeast extract; $0.06 \%$ of $\mathrm{MgSO}_{4} .5 \mathrm{H}_{2} \mathrm{O} ; 1 \%$ of $\mathrm{KH}_{2} \mathrm{PO}_{4} ; 0.2 \%$ of $\mathrm{CaCl}_{2} \cdot 6 \mathrm{H}_{2} \mathrm{O}$ : $0.2 \%$ of $\mathrm{K}_{2} \mathrm{HPO}_{4}$ have been added. For this, three media were reconstituted. Medium1 : Galactose, Yeast extract $\mathrm{MgSO}_{4} .5 \mathrm{H}_{2} \mathrm{O}: 0.06 \%$; $\mathrm{KH}_{2} \mathrm{PO}_{4}: 0.1 \%$; $\mathrm{CaCl}_{2} \cdot 6 \mathrm{H}_{2} \mathrm{O}: 0.2 \% ; \mathrm{K}_{2} \mathrm{HPO}_{4}: 0.2 \%$. Medium 2: Mannose, Yeast extract $\mathrm{MgSO}_{4} \cdot 5 \mathrm{H}_{2} \mathrm{O}: 0.06 \%$; $\mathrm{KH}_{2} \mathrm{PO}_{4}: 0.1 \%$; $\mathrm{CaCl}_{2} \cdot 6 \mathrm{H}_{2} \mathrm{O}: 0.2 \% ; \mathrm{K}_{2} \mathrm{HPO}_{4}: 0.2 \%$. Medium 3: Starch Yeast extract $\mathrm{MgSO}_{4} .5 \mathrm{H}_{2} \mathrm{O}: 0.06 \%$; $\mathrm{KH}_{2} \mathrm{PO}_{4}: 0.1 \%$; $\mathrm{CaCl}_{2} .6 \mathrm{H}_{2} \mathrm{O}: 0.2 \% ; \mathrm{K}_{2} \mathrm{HPO}_{4}: 0.2 \%$ These media are then sterilized ${ }^{14,15,16}$

\section{Nitrogen sources}

In order to study the effect of the nitrogen source on the growth and production of extracellular enzymes of three Bacillus strains, a carbon source (starch) and the following mineral substances $\mathrm{MgSO}_{4} .5 \mathrm{H}_{2} \mathrm{O}: 0.06 \%, \mathrm{KH}_{2} \mathrm{PO}_{4}: 0.1 \%$, $\mathrm{CaCl}_{2} \cdot 6 \mathrm{H}_{2} \mathrm{O}: 0.2 \%, \mathrm{~K}_{2} \mathrm{HPO}_{4}: 0.2 \%$ have been fixed. Then we varied the sources of nitrogen. Thus two media were prepared: one containing the yeast extract, starch and mineral substances and the other containing the bactopeptone, starch and mineral substances. These media are then sterilised. The culture condition was carried out as described above $\mathrm{e}^{14,15,16}$

\section{RESULTS}

\section{Evidence of proteolytic enzyme production}

Fig. 1 shows translucent halos used as an indicator of proteolytic enzyme production. These vary in diameter from 1 to $3.5 \mathrm{~cm}$.

Influence of temperature on growth and enzyme production growth

The profile of the influence of temperature on growth is shown in the Fig. below (Fig. 2). This influence obtained by plotting the optical density evolution curves that express the growth of Bacillus strains (CMS5, CMS4 and SPo5 14'). For temperatures between 25 and $30^{\circ} \mathrm{C}$, an increase in optical density observed which proportional to the increase in temperature. Optimum was obtained at $30^{\circ} \mathrm{C}$ for all three (3) strains. However, from 37 to $55^{\circ} \mathrm{C}$ the increase in optical density becomes inversely proportional to the increase in temperature and, above $55^{\circ} \mathrm{C}$ the optical density decreases progressively and tends to cancel out from $60^{\circ} \mathrm{C}$ onwards.

\section{Enzymatic production}

In order to determine the optimal temperature for the production of exo-cellular enzymes for the 3 strains, halo diameter development curves expressing the excretion of exo-cellular enzymes as a function of temperature variation were established in the Fig. below (Fig. 3) over a temperature range of 25 and $60^{\circ} \mathrm{C}$.

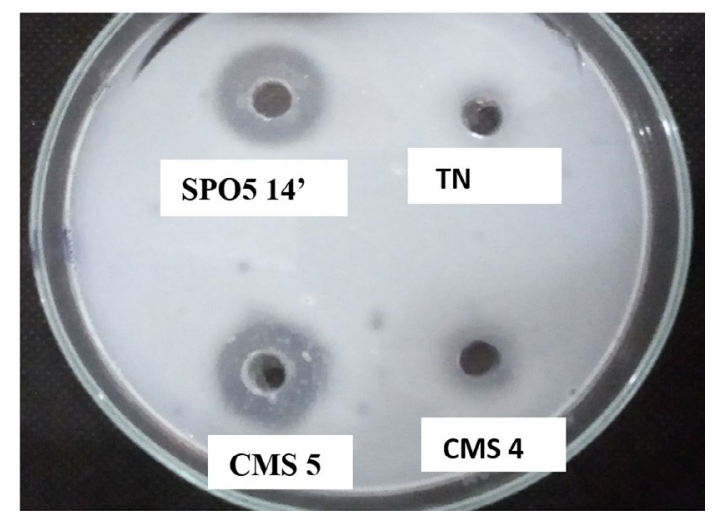

Fig. 1. Translucent halos indicating the digestion of casein by the enzymes produced by Bacillus trains. TN: Negative control 
The simple observation of this Fig. clearly shows that $37^{\circ} \mathrm{C}$ the favourable temperature for the production of enzymes for Bacillus subtilis and Bacillus velenzensis strains and $30^{\circ} \mathrm{C}$ for Bacillus sp. Above $37^{\circ} \mathrm{C}$ production decreases considerably.

\section{Growth kinetics over time}

The curves in Fig. 4 show the growth kinetics of CMS5 (Bacillus Subtilis); CMS4 (Bacillus sp.) and SPo5 14' (Bacillus Velenzensis) as a function of time. All curves show the same pattern. In CMS5 and SPO5 14'; from 8 h to 24h, the growth increases gradually, and is proportional to time. However, from $24 \mathrm{~h}$ to $26 \mathrm{~h}$, despite the increase in time, there a stabilisation of the optical density. expressing the stabilisation of growth (optical density). Beyond 26 hours, growth (optical density) becomes inversely proportional to time.
At CMS4; $8 \mathrm{~h}$ to $24 \mathrm{~h}$, microbial growth increases progressively until it reaches a peak and from 24 $\mathrm{h}$ then it remains stable until $32 \mathrm{~h}$. From 32 hours onwards, growth decreases and becomes inversely proportional to time.

The growth curves obtained for the three strains have the same phases: exponential growth phase, stationary phase and a phase of diminishing growth (Fig. 4). An analysis of these curves reveals that there no latency phase; certainly because we used overnight culture with germs taken in exponential phase and the same culture medium. In fact, in the exponential growth phase, the bacterial cells divide continuously, as long as nutrients are available and toxic substances are absent at the optimal neutral $\mathrm{pH}$ (7). As the physiological state maximal, so the growth rate.

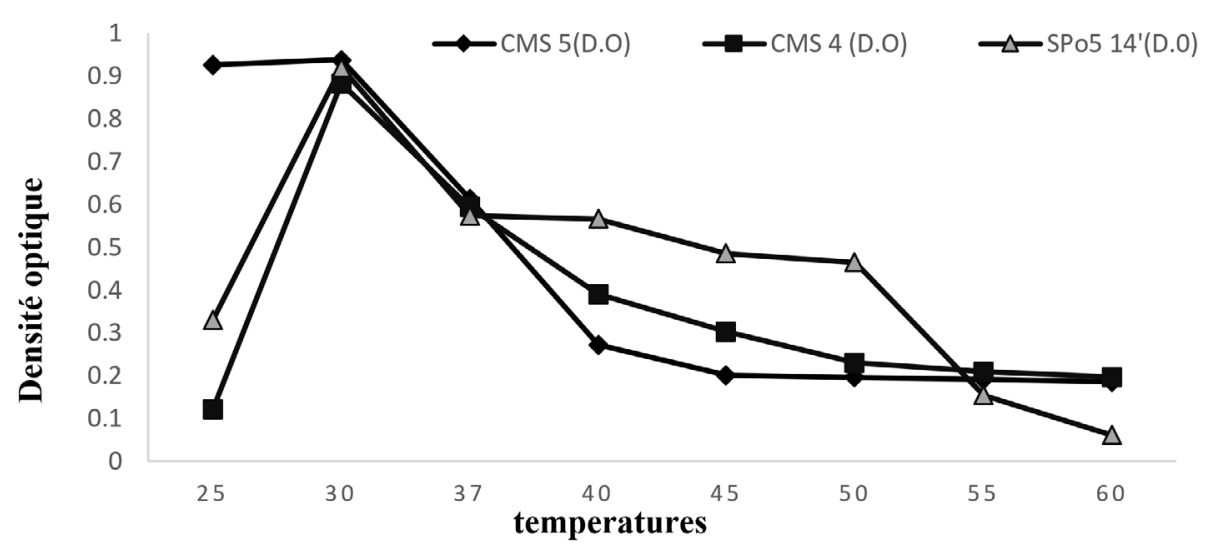

Fig. 2. Growth in CMS5 (Bacillus subtilis), CMS4 (Bacillus sp.) and SPo5 14' (Bacillus velenzensis) as a function of temperature

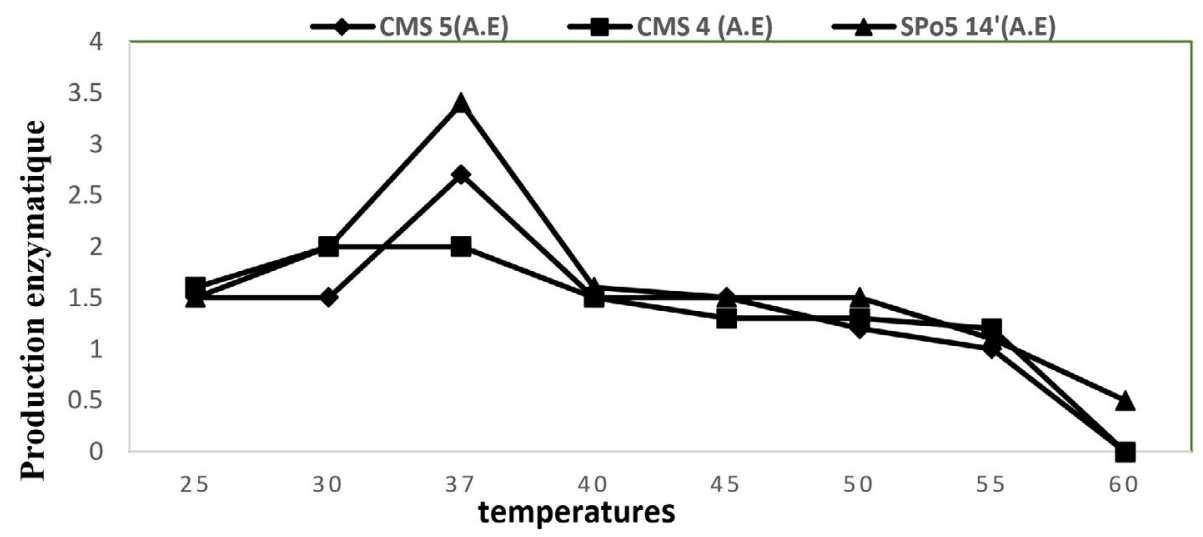

Fig. 3. Enzyme production in CMS5 (Bacillus subtilis), CMS4 (Bacillus sp.) and SPo5 14' (Bacillus velenzensis) as a function of temperature. 
In the stationary phase, nutrients are depleted, toxic substances accumulate and the $\mathrm{pH}$ rises to 8. The number of cells no longer varies. There as much cell division as cell death. The growth rate constant. We even speak of cryptic growth, where cells feed on the contents released by dead cells. Finally, in a phase of decline, the cells no longer divide, they die by cell lysis by the enzymes released at the moment of their death.

\section{Evolution of the $\mathrm{pH}$ as a function of time}

The results of the $\mathrm{pH}$ of the bacterial suspension as a function of time are shown in the Fig. below (Fig. 5). It can be seen that there an increase in $\mathrm{pH}$ as a function of time for all three (3) strains. From 8 to 10 hours the $\mathrm{pH}$ is equal to 6 for all three strains. From 12 to 26 hours it rises to 7 and from 28 to 30 hours it rises to 8 .

The effect of $\mathrm{pH}$ on growth and enzymatic production

\section{Effect of pH on growth}

The choice of the $\mathrm{pH}$ upstream in the monitoring of growth in a culture medium important. Fig. 6 shows the influence of $\mathrm{pH}(5$, 7 and 9) on growth in the three strains Bacillus subtilis Bacillus sp. and Bacillus velenzensis. The best growth obtained at $\mathrm{pH} 7$ (neutral) for all strains. However, growth possible at $\mathrm{pH} \mathrm{5,7}$ and 9.

\section{Effect of pH on enzyme production}

The $\mathrm{pH}$ is a major factor and plays an important role in the enzyme production process. It can lead to an increase or decrease in the increased production of enzymes (Mathieu Dourin 2015). Fig. 7 shows the effect of the $\mathrm{pH}$ of the medium on the enzyme production of the three Bacillus strains: Bacillus subtilis, Bacillus sp. and Bacillus velenzensis. Enzyme production is possible from $\mathrm{pH} 5,7$ to 9 .

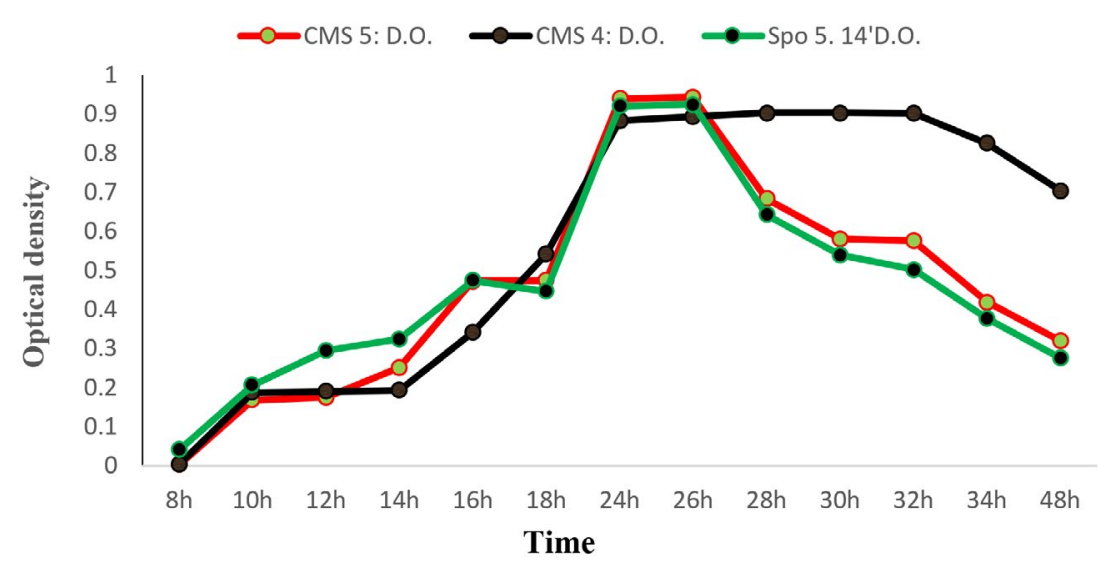

Fig. 4. Growth kinetics in Bacillus subtilis (CMS5), Bacillus sp. (CMS4) and Bacillus velenzensis (SPo5 $\left.144^{\prime}\right)$ as a function of time.

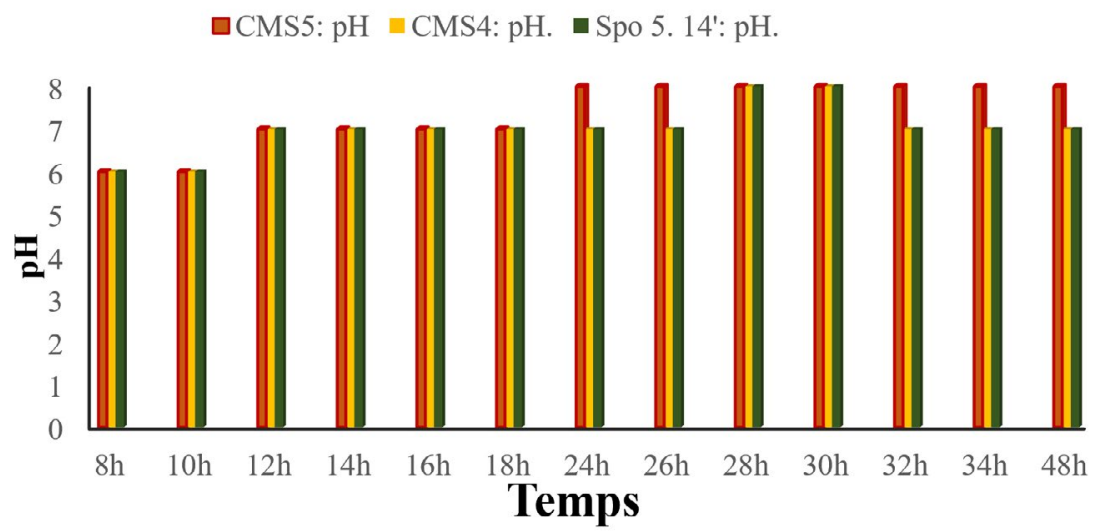

Fig. 5. Evolution of $\mathrm{pH}$ as a function of time 


\section{Effect of carbon sources on growth and enzymatic production}

Fig. 8 shows that the choice of carbon sources in the culture medium is necessary for enzyme production, as each microorganism has different physiological properties. Observation of this Fig. tells us that galactose has proven to be the best source of carbon for growth. On the other hand, starch proved to be the best source of enzyme production after 24 hours of incubation. The effect of nitrogen sources on growth and enzyme production

The influence of nitrogen sources in the fermentation and production environment was studied. The results of the three strains are shown in Fig. 9. Analysis of the results in this Fig. shows that Bacto-peptone is the correct component for growth and enzyme production in all three strains.

\section{DISCUSSION}

Optimising the temperature for bacterial growth is an important procedure. The optimal temperature for growth of three strains $30^{\circ} \mathrm{C}$. These results are similar to those obtained by ${ }^{7,16}$ using other strains of the same origin, but these results differ from those of ${ }^{9}$ for this work on growth



$\begin{array}{lll}\square \mathrm{pH} 5 \text { CMS } 5 & \mathrm{pH} 5 \mathrm{CMS} 4 & \mathrm{pH} 5 \text { SPo5 } 14^{\prime} \\ \square \mathrm{pH} 7 \mathrm{CMS} 5 & \mathrm{pH} 7 \mathrm{CMS} 4 & \mathrm{pH} 7 \mathrm{SPo} 514^{\prime}\end{array}$

Fig. 6. Effect of pH on growth in three Bacillus strains: Bacillus subtilis (CMS5), Bacillus sp. (CMS4) and Bacillus velenzensis (SPo5 14')

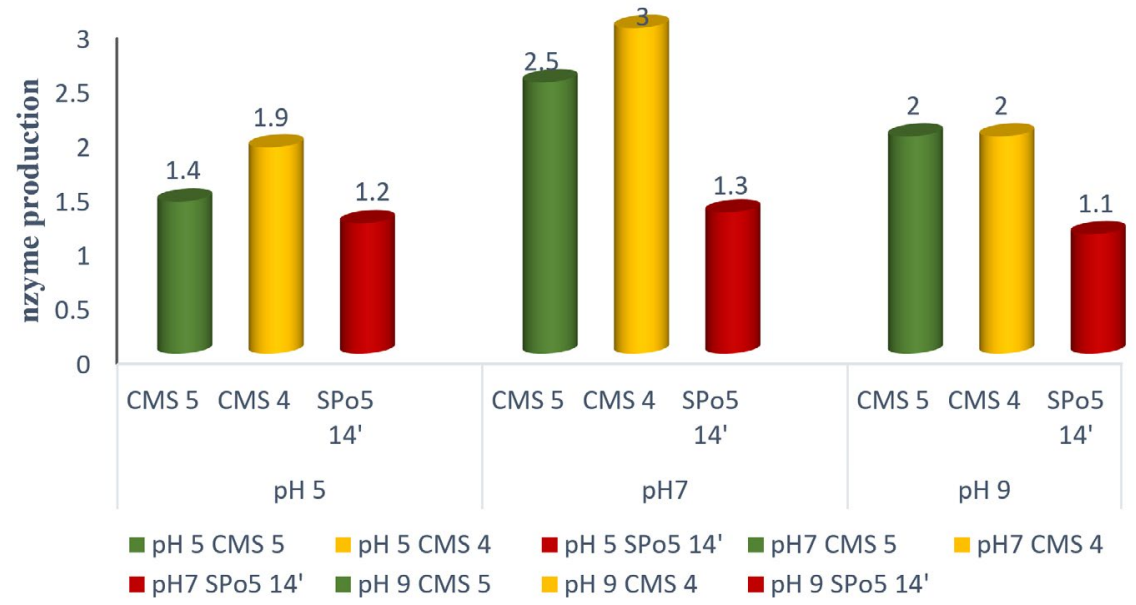

Fig. 7. Effect of $\mathrm{pH}$ on the enzyme production of three Bacillus strains: Bacillus subtilis (CMS5), Bacillus sp. (CMS4) and Bacillus velenzensis (SPo5 14'). 
optimisation, fibrinolytic enzyme production and PCR amplification of genes encoding fibrinolytic enzymes in two Bacillus amyloliquefaciens strains (Ba NM76 and Ba NM 77) isolated from Ntoba mbodi in Congo Brazzaville.

The results presented on the demonstration of the enzyme production of the three (3) strains show that these strains produce proteolytic enzymes with a caseinolytic effect. $37^{\circ} \mathrm{C}$ the optimal temperature for enzyme production for the Bacillus subtilis and Bacillus velenzensis strains and $30^{\circ} \mathrm{C}$ for Bacillus sp. These results are identical to those published by ${ }^{17}$. But differ from those found by ${ }^{7,16}$ on the Ntoba bodi which found $35^{\circ} \mathrm{C}$ as the optimal temperature for enzyme production.

Under the same growing conditions, all strains have different enzyme production profiles. This study has given results that agree with these rules. Many authors have claimed these rules, such as $^{18,19,20}$

The growth kinetics of three (3) strains gave a different pattern of curves from the results obtained by ${ }^{15}$ with the presence of a latent phase in the growth curve a different method by the type of culture used, nevertheless these results are almost identical to those published by ${ }^{21}$.

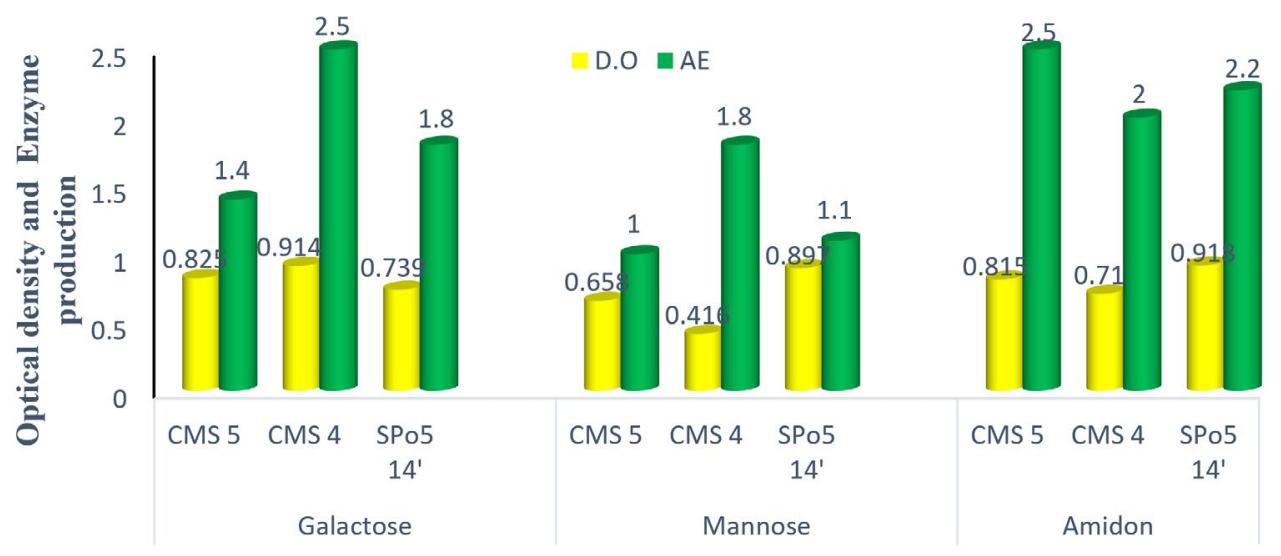

Fig. 8. The effect of carbon sources on the growth and production of three strains of Bacillus: Bacillus subtilis (CMS5), Bacillus sp. (CMS4) and Bacillus velenzensis (SPo5 14').

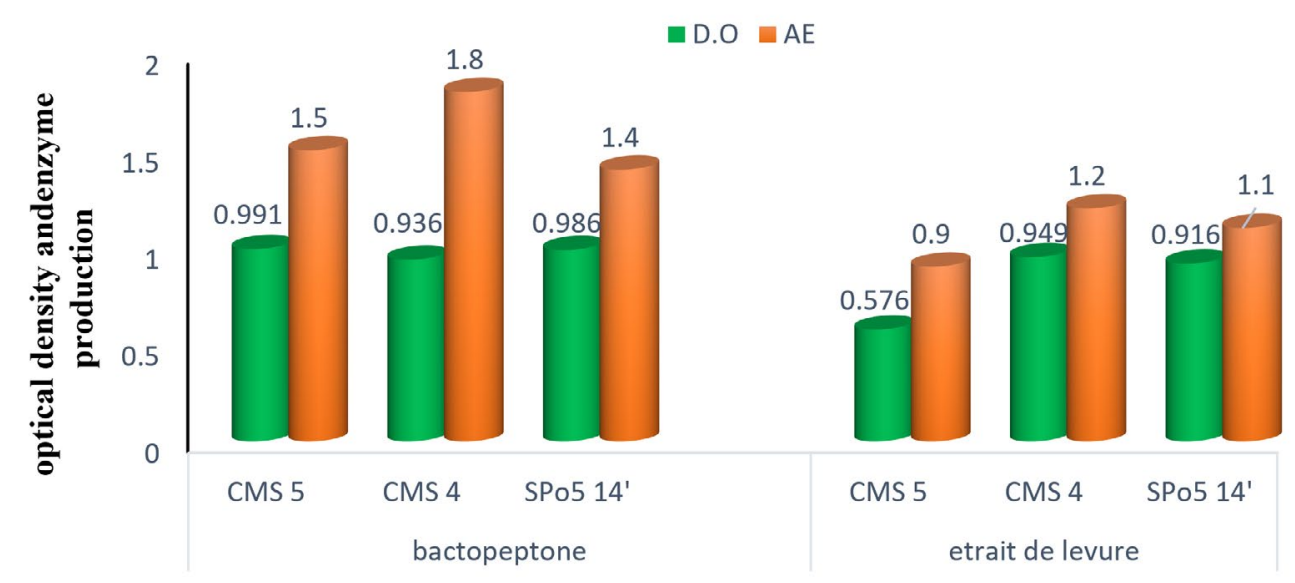

Fig. 9. The effect of nitrogen sources on the growth and enzymatic production of three Bacillus strains: Bacillus subtilis (CMS5), Bacillus sp. (CMS4) and Bacillus velenzensis (SPo5 14'). 
The results presented on the demonstration of the enzyme production of the three (3) strains show that these strains produce proteolytic enzymes with a caseinolytic effect. This study gave similar results to those published by 22,23 . Growth is possible at any pH. The optimum was obtained at $\mathrm{pH} 7$. These results are in line with those obtained in other studies carried out on Ntoba Nbodi ${ }^{7,16}$

Based on data provided by other researchers, the proteolytic enzyme production media of the different strains were adjusted to different $\mathrm{pH}$ values. Since the optimal $\mathrm{pH}$ for all strains was 7 , these results are comparable to previous results on Ntoba Nbodi ${ }^{7,16,24}$ which showed that the optimal pH for enzyme production was 7. However, our results differ from those found by ${ }^{17}$ where the best production was obtained at $\mathrm{pH} 8$ but also differ from those found by ${ }^{25}$ where the optimal $\mathrm{pH}$ for production was 9 .

Among the carbohydrates that have been used as a source of carbon, galactose has proven to be the best for growth. On the other hand, starch proved to be a better source of enzyme production after 24 hours of incubation, results which are consistent with those of ${ }^{7}$ but different from those published $i^{26}$ with glucose (monosaccharide) as the best source of production. Galactose promotes significant growth while starch promotes better enzyme production. This result probably explained by the fact that galactose and mannose are monosaccharides. The strains easily metabolise these carbon sources and the source is rapidly depleted. Hence the low enzyme production, whereas starch a polysaccharide, the strains metabolise slowly and the source is always available in the medium for good enzyme production.

Results on nitrogen sources have been determined. Although growth and enzyme production is observed with the yeast extract, Bacto-peptone would therefore be the best nitrogen source to produce enzymes in significant quantities. These results differ from those of 7,26 who obtained the best growth and enzyme production with yeast extract.

\section{CONCLUSION}

In the end, this work made it possible, among other things, to determine the effect of the various external factors studied in this modest study of the three strains of Bacillus: CMS5 (Bacillus Subtilis), CMS4 (Bacillus sp.) and SPo5 14' (Bacillus Velenzensis) isolated from squashes. Proteolytic activity was demonstrated on a medium containing skim milk mixed with agarose. The results obtained showed that the three strains are relatively capable of carrying out proteolysis generating a halo up to $3.5 \mathrm{~cm}(35 \mathrm{~mm})$ in diameter.

The set of methods used made it possible to determine the external factors influencing the growth and production of the proteolytic enzymes tested, one factor having a significant effect on the production of the enzyme which temperature, starch and Bacto-peptone of $(0.5 \mathrm{~g} / 100 \mathrm{ml})$ being the best sources of carbon and nitrogen respectively.

\section{ACKNOWLEDGMENTS}

I would like to express my deepest gratitude and appreciation to all those who have contributed to this work. More particularly to Dr. Etienne NGUIMBI and Dr. Cyr Jonas MORABANDZA, both CAMES Lecturers and Researchers at the Faculty of Science and Technology, Marien NGOUABI University, Brazzaville Congo, for their contribution to this modest work.

\section{CONFLICT OF INTEREST}

All authors declare that there is no conflict of interest.

\section{AUTHORS' CONTRIBUTION}

All authors listed have made a substantial, direct and intellectual contribution to the work, and approved it for publication.

\section{FUNDING}

None.

\section{DATA AVAILABILITY}

All datasets generated or analyzed during this study are included in the manuscript.

\section{ETHICS STATEMENT}

Not applicable.

\section{REFERENCES}

1. Guendouz F, Belibel S. Study of the protease production potential of mycelial strains isolated from arid 
zones. Master's thesis, Faculty of Natural and Life Sciences, Department of Microbiology, University of Constantine. 2014; 1. p:1-51.

2. Demain A.L.Microbiol Biotechnology (feature). Trends in biotechnology. 2000;18(1):26-31. doi: 10.1016/ S0167-7799(99)01400-6

3. Perez J, Munoz-Dorado J, de la Rubia T, Martinez J. Biodegradation and biological treatments of cellulose, hemicellulose and lignin: an overview. Int Microbiol. 2002;5(2):53-63. doi: 10.1007/s10123-002-0062-3

4. Opatokun SA, Nassereldeen AK, Zahangir MdA, Aliyu Sa, Alade A, Tijani lyabo DR .Composting of food and yard wastes by locally isolated fungal strains. Afr J Biotechnol. 2011;10:18800-18806. doi: 10.5897/ AJB11.2756

5. Meriem C, Sihem A, Yasmine B. Study of some enzymatic activities of a collection of actinomycetes. Master's thesis, University of Mentouri Constantine Brothers Faculty of Natural and Life Sciences. 2016 p : 18-102.

6. Bensmira S .Isolation and characterisation of fungal strains from extreme environments (Sol and Sebkha from the Biskra region) producing thermostable cellulase of industrial interest. Magister memory. University of Mentouri. Constantine 2006.

7. Soloka MFA, Moyen R, Nguimbi E, et al. Optimisation of growth conditions and production of caseinolytic protease in two Bacillus strains isolated from ntoba mbodi, faculty of sciences and techniques, Marien Ngouabi university. 2017; P: 2-76

8. Soloka MFA, Nguimbi E, Kayath AC, Ahombo G, Molecular Characterization of Bacillus-Genus Bacteria with Fibrinolytic Potential Isolated from Squashes "NTETE» in Brazzaville in the Republic of Congo. American Journal of Microbiological. 2020;1:7-18. doi: 10.12691/ajmr-8-1-2

9. Nguimbi E, Ahombo G, Moyen R, et al. Optimization of Growth, Fibrinolytic Enzyme Production and PCR Amplification of Encoding Fibrinolytic Enzyme Gene in Bacillus amyloliquefaciens Isolated from Ntoba mbodi at Brazzaville. International Journal of Science and Research (IJSR). 2014;11(3): 2799 - 2803

10. Astrup T, Mullertz S. The fibrin plate method for estimating fibrinolytic activity. Arch. Biochem. Biophys. 1952; 40;346-351. doi: 10.1016/0003-9861(52)901215

11. Kim S, Choi NS. Electrophoresis analysis of protease inhibitors in fibrin zygmography. Anal. Bochem. 1999; 270:179-181. doi: 10.1006/abio.1999.4080

12. Cooney NL, Levine DW. Microbial utilization of methanol. - Adv. Appl. Microbiol. 1972; 15:337-365. doi: 10.1016/S0065-2164(08)70096-0

13. Mohamed L, Reda C, Mohamed EY, Mohamed O, Hassan EB, Mohamed J. Optimisation of growth and production of extracellular glucoamylase by Candida guilliermondii . Bull. Soc. Pharm. Bordeaux. 2007; 253, 251-270
14. Nguimbi E, Wu Zhi R. Production of a New Fibrinolytic Enzyme, Bacterium Growth and Enzyme Production Conditions. Purification and characterization of the New Enzyme. Biotechnology. 2002;12(2).

15. Kannan N, Aravindan R, Viruthagiri T. Effect of culture conditions and kinetic studies on extracellular tannase production by LactoBacillus plantarum (MTCC1407.). Indian Journal of Biotechnology. 2011; 10:321-328

16. Kimbembe JP. Production, optimisation and partial purification of caseinolytic protease produced by Bacillus subtilis and Bacillus pumilus isolated from ntoba mbodi, Ecole Normafaculté des sciences et techniques, Université Marien Ngouabi. 2016 p: 2-76.

17. Monisha, JN, Divya M, Praveen $\mathrm{PH}$, Vidyashree $\mathrm{N}$, Mahesh M, \& R, I. P .Optimization for the production of fibrinolytic enzyme from halophiles and its application, International Journal of Advanced Scientific Research and Publications (IJASRP). 2005; 1 -7.

18. Ji-Hyun S, Sam-Pin L. Production of Fibrinolytic Enzyme from Soybean Grits Fermented by Bacillus firmus NA1. Journal of Medicinal Food. 2004;7(4):442-449. doi: 10.1089/jmf.2004.7.442

19. Peng MY, Yang $X$, Zhang Y. Microbial fibrinolytic enzymes: An overview of source, production, properties, and thrombolytic activity in vivo. 2005;126132. doi: 10.1007/s00253-005-0159-7

20. Anjana S, Sharma A, Shivlata L . Optimization of Medium Components for Enhanced Production of Extracellular Fibrinolytic Protease from Citrobacter braakiilnt. Int. J.Curr.Microbiol.App.Sci. 2015;4(7): 248-259

21. Drouin M. Study of the production of alkaline proteases by bacill us licheniformisen using municipal sewage sludge as substrate, Thesis presented for the degree of Master of Science (M.Sc.), Microbilogy, National Institute of Scientific Research. 2005;142:pp 17-18

22. Wilkesman J, Kurz L. Protease Analysis by Zymography: A review on techniques and patents. Recent Patents on Biotechnol. 2009;3:175-184. doi: 10.2174/187220809789389162

23. Faiza M, Manel Y .Production of alkaline protease by isolated thermal spring moulds on chicken feather medium. Dissertation for the Master's degree in Biological Sciences. Université des frères mentouri constantine Algeria. (2015).

24. Inkyung $\mathrm{P}$, Cho J. Production of an extracellular protease by an Antarctic bacterial isolate (Bacillus sp. JSP1) as a potential feed additive. Revista Colombiana de Ciencias Pecuarias. 2011:24:3-10.

25. Sinha P, Singh KR, Srivastva R, Sharma R, Tiwari SP. Characterization and optimization of alkaline protease enzyme produced by soil borne bacteria www. sciencejournal.in.2013.

26. Boominadhan U, Rajakumar R. Optimization of Protease Enzyme Production Using Bacillus Sp. Isolated from Different Wastes. Botany Research International. 2009; 2(2): 83-87. 